\title{
Teacher perceptions of the contribution of home economics to sustainable development education: A cross-cultural view
}

\author{
Yvonne Dewhurst \& Donna Pendergast
}

Corresponding author:

Professor Donna Pendergast

Griffith University

d.pendergast@griffith.edu.au

Yvonne Dewhurst

The University of Aberdeen 


\section{Teacher perceptions of the contribution of home economics to sustainable development education: A cross-cultural view}

\section{ABSTRACT}

This paper reports on the contribution of home economics to sustainable development education as part of the school curriculum for students aged 11-18 years, in a number of cultural contexts. A survey was used to collect data from home economics teachers in Australia, Canada, Malta and Scotland to better understand the similarities and differences of home economics curriculum in these contexts, as it contributes to sustainable development education. The data reveals that the teachers in the study considered sustainable development to be an important issue and the formal home economics curricula made significant contributions to the education of this topic. It is noted however that the field of sustainable development education has neglected studies of home economics education and its teachers' perceptions about sustainable development education, and this is reinforced by a lack of research generated from the home economics field. The researchers argue that this is an inhibiting factor affecting the capacity of schools to achieve sustainable development goals.

\section{INTRODUCTION}

\section{Sustainability}

The issue of sustainability has been on the agenda of environmental education for several decades. Climate change and altered weather patterns, global warming, exhaustion of fisheries, desertification and degradation of agricultural land and pollution are reported to be some of the main threats to our environment and its inhabitants (Oskamp, 2000). In 1992 the Union of Concerned Scientists cautioned on the economic, social, environmental and technological developments by human beings, warning that:

$[\mathrm{H}]$ uman beings and the natural world are on a collision course. Human activities inflict harsh and often irreparable damage on the environment and critical resources. ... if not checked, many of our current practices put at serious risk the future that we wish for human society and the plant and animal kingdoms and so, may alter the living world that it will be unable to sustain life in the manner we know. A great change in our stewardship of the earth and the life on it is required... (Suzuki, 1993, p4).

In 2005, the most comprehensive and rigorous survey of the ecological state of the planet concluded that human society has caused irreversible changes that are degrading the ecological processes that support life on earth (Millennium Ecosystem Assessment Board, 2005), adding power and urgency to search for solutions. A survey of experts in nine countries (Smyth \& Shacklock, 1998), east and west, illustrated consensus on characteristics required by future global citizens and ranked them as follows:

- looking at problems in a global context;

- $\quad$ working co-operatively and responsibly;

- accepting cultural difference;

- thinking in a critical and systematic way; 
- solving conflicts non-violently;

- changing lifestyles to protect the environment;

- defending human rights; and

- participating in politics.

But where is the formal education process that develops these desirable skills and capabilities? What does sustainable development education look like in schools? Does home economics curriculum contribute to sustainable development education, and if so, how does it vary around the world?

\section{Sustainable Development Education}

The search for effective sustainable development grew in the 1990s. A world ethic of sustainability that effects change in human practices and attitudes founded on co-operation with each other and the planet for the survival and wellbeing of every individual and the biosphere, was advocated as a priority in global forums (IUCN, 1980; UNEP, 1990; Fien, 1993). As the discourse on sustainable development evolved, a shift of emphasis could be seen in different policies and international documents. Three historically important documents - The Belgrade Charter (UNESCO-UNEP, 1976), The Tbilisi Declaration (UNESCO, 1997) and Agenda 21 (UNESCO-UNEP, 1992) record aims and basic principles for the context of their times. The Belgrade Charter called for awareness, knowledge, skills, values and participation to preserve the natural environment and to reduce human impacts, with little emphasis given to the quality of life. It was only later in Agenda 21 that concern for the human aspects (i.e. quality of life, standard of living, gender, human rights, social justice and democracy) and built environments was addressed. The blend was now balanced and inclusive of both environment and society. Agenda 21, with a call for education in every chapter, highlighted the role of education as a change agent for this, stating:

[E]ducation is critical for promoting sustainable development and improving the capacity of the people to address environment and development issues...It is critical for achieving environmental and ethical awareness, values and attitudes, skills and behaviour consistent with sustainable development and for the effective public participation in decision-making (UNESCO-UNEP, 1992, p.2).

As highlighted in this document, it is necessary to distinguish between education about sustainable development and education for sustainable development. The former is the awareness raising, theoretical discussion while the latter uses education as a tool to achieve sustainable development.

In Living Beyond Our Means: Natural Assets and Human Well-Being (2005) the Millennium Ecosystem Assessment Board reiterated the importance of education to make an impact. In addition, the United Nations (2002) declared 2005-2014 the Decade of Education for Sustainable Development (DESD), locating education at the centre of a range of means to achieve a sustainable world.

In the document, Guidelines and Recommendations for Reorienting Teacher Education to Address Sustainability (McKeown \& Hopkins, 2003) the importance of the world's $59,000,000$ teachers to educate for developing understandings about sustainable development is articulated and strategies for action outlined. It is argued that "the core themes of education for sustainability include lifelong learning, interdisciplinary education, partnerships, multicultural education and empowerment” (UNESCO, 2005, p.15). 
McKeown and Hopkins (2003) urge a multidisciplinary approach, noting that "no one discipline can or should claim ownership of Education for Sustainable Development" (2005:np). Many ecological curriculum theorists have called for a broader understanding of interconnections among society, economy and the environment (Van Kanner-Ray, 2006, Hopkins and McKeown, 2002,) and this has been recently endorsed in the UNESCO Strategy for the $2^{\text {nd }}$ half of the UN Decade of Education for Sustainable Development (UNESCO, 2010). One of its key characteristics is to teach sustainability education using an interdisciplinary approach, not in independent subject silos. However, few countries have thoroughly integrated multidisciplinary teaching into their curricula.

Many pedagogical models exist, yet Gruenwald and Manteaw (2007, p.173) note that sustainability is "marginalised, misunderstood as mainly about science, and in many places, totally neglected". More recently, despite countless international efforts to integrate schools with ecological perspectives, it remains peripheral to mainstream curricula (Moroye, 2009). There may be many reasons for this neglect or 'failure' (Blumenstein \& Saylan, 2007) and if we are to look for future success, then we should consider the work of teachers. As Craig (2009) argues, curriculum and teaching are inextricably linked and the teacher-ascurriculum-maker is a complex phenomenon that is characterised by teachers' reflections, beliefs, interpretations and resulting actions which extend beyond the curricular programme as written. He, Phillion, Chan \& Xu (2008, p. 223) offer a broad definition of curriculum:

[C] urriculum for us is a dynamic interplay between experiences of students, teachers, parents, administrators, policy-makers, and other stakeholders; content knowledge and pedagogical premises and practices: cultural, linguistic, socio-political, and geographical contexts.

Here teachers' experiences and classroom practice result from teachers own values and beliefs. Although the propensity for adopting sustainability depends on teacher's attitudes towards or receptivity, it may not be an accurate predictor of implementation (Morris, 1996; Gough, 1997). Teachers' attitudes can be crucial in determining success or failure (Richardson, 1991). Moroye (2009) and Smith (2004) found that beliefs are not separate from teachers' practice but are integral to who they are in the classroom. Their beliefs inform their practice, guide curriculum choices, emphases and omissions.

It is in this context that this study was designed to explore the intentions, beliefs and practices of home economics teachers with respect to the teaching of sustainable development education in schools for 11-18 year old students.

\section{Sustainable Development Education and Home Economics}

The societal goals of sustainability as presented by UNESCO (2010) are: environmental stewardship; social equity, justice and tolerance; and quality of life for all people in this generation and the next - all of which, but particularly the latter, resonate with home economics in the context of both education and as a profession which has sustainable development incorporated as a fundamental guiding principle. Its disciplinary diversity and aim of achieving optimal and sustainable living means home economics has the potential to impact on many sectors of society at global levels. This is driven by professional ethics, "based on the values of caring, sharing, justice, responsibility, communicating, reflection and visionary foresight” (UNESCO, 2010, p. 1).

Home economics is a subject studied around the world, and is defined by the International Federation for Home Economics (IFHE) in its Position Statement Home Economics in the 
$21^{\text {st }}$ Century as a "field of study and a profession, situated in the human sciences that draws from a range of disciplines to achieve optimal and sustainable living for individuals, families and communities" (IFHE, 2008, p.1). The position statement argues that the profession is currently enjoying renewed attention because of its "imperative of improving the world in which we all live such that sustainable development is possible” (IFHE, 2008 p.2).

Regardless of this claim, sustainable development education research has neglected studies of home economics and its teachers' perceptions as factors affecting the capacity of schools to achieve sustainable development goals. One study of initial teacher education programs in America (Heimlich, Braus, Olivolo, McKeown-Ice \& Barringer-Smith, 2004) found that almost a fifth of the programs incorporate environmental education into a discipline. The strongest perceived fit by teacher educators was into environmental sciences with family living/home economics trailing towards the end as a perceived fit.

In offering direction for home economics, Pendergast (2006) suggests that the subject is at a convergent moment. A number of interconnected societal factors such as sustainability, global consumption, health and social justice are aligning around the profession. There is therefore growing alignment with the intentions of home economics to play a pivotal role in the development of informed global citizenry. Dewhurst and Pendergast $(2008,2009)$ noted several socially just and ethical practices of home economics teachers in Australia, Malta and Scotland, suggesting that home economics contributes to giving young people a sense of their own agency as well as a sense of social responsibility towards and with others. Arai (2008) and Nielson and Gottschau (2008) also argue for a nurturance of action-oriented consumer citizens who actively practice and promote sustainable development in everyday life.

\section{THE STUDY}

This aim of this study was to explore the intentions, beliefs and practices of home economics teachers with respect to sustainable development education, from a cross-cultural perspective. Respondents were from Australia, Canada, Malta and Scotland, which were convenience locations for this study. This cross-cultural dimension was added to explore similarities and differences across locations, and to emphasise the global reach of the subject of home economics in schools.

\section{The Instrument}

A survey was designed which elicited quantitative and qualitative data from respondents. There were 8 questions comprising a combination of open-ended and Likert scale responses. The survey included questions assessing demographic information on age and country, plus the following items: how long teachers had been teaching; how strongly (or not) they felt about sustainability; their current approaches; their definition of sustainable development education; who is responsible for teaching about sustainability; the inhibitors/enablers which affect their teaching of sustainability; current departmental practice regarding sustainability; and the areas of sustainability they are interested in teaching. The items in the survey were piloted and checked by a small sample of teaching practitioners before being adjusted and used in the main study.

\section{Sampling Technique}

A convenience sampling method was used where the researchers and colleagues of the researchers were invited to distribute the surveys as widely as possible at events such as 
conferences. The researchers collected data in Scotland and in Australia, both using the opportunity to administer the survey at conferences, and colleagues collected data in Malta and in Canada. A 6 month data collection window was allowed. Convenience sampling provides a non-representative dataset, hence it cannot be assumed that the data provided is representative of all home economics educators in Canada, Australia, Scotland and Malta. However, it provides a snapshot of responses from the four countries where respondents were located.

\section{The respondents}

A total of 186 respondents are included in the data analysis. This is comprised of the following subsets: Canada $=15$ respondents; Malta $=15$ respondents; Scotland $=77$ respondents and Australia $=79$ respondents.

\section{Data Analysis}

Quantitative data were analysed using descriptive statistical analysis. The qualitative data were analysed using a traditional means of content analysis which is "a research technique for making replicable and valid inferences from texts (or other meaningful matter) to the contexts of their use” (Krippendorff, 2004, p.18). Cavana, Delahaye \& Sekaran’s (2003) fifteen stages of content analysis (based within the constant and comparative method) was used as a guide to identify key themes and meaning. Themes were located and frequency counts conducted. Coding for manifest content (Wallen \& Fraenkel, 2001) was used, which means that what was directly written as opposed to latent content which is implied, was used for the content analysis. The overall analytic process was an inductive, ongoing cyclical process in which patterns emerged from the data.

\section{RESULTS}

\section{The respondents}

Minimal demographic information was requested of respondents. For each respondent their country and the number of years they had been teaching were requested. With the exception of Malta, the majority of teacher respondents in the study had been teaching for over 10 years, with the Scottish cohort notable with over $40 \%$ of the total of 77 respondents teaching for more than 21 years. The Malta respondents differed from the other country responses in that almost $40 \%$ of the 15 respondents were in their first 3 years of teaching and of the remainder, 25\% were currently studying to become teachers. This reflects the access of the researchers rather than any other factor, but should be considered in interpreting results from the survey

Figure 1: Respondents years of teaching: Comparison of responses from Scottish, Australian, Canadian and Maltese teachers 


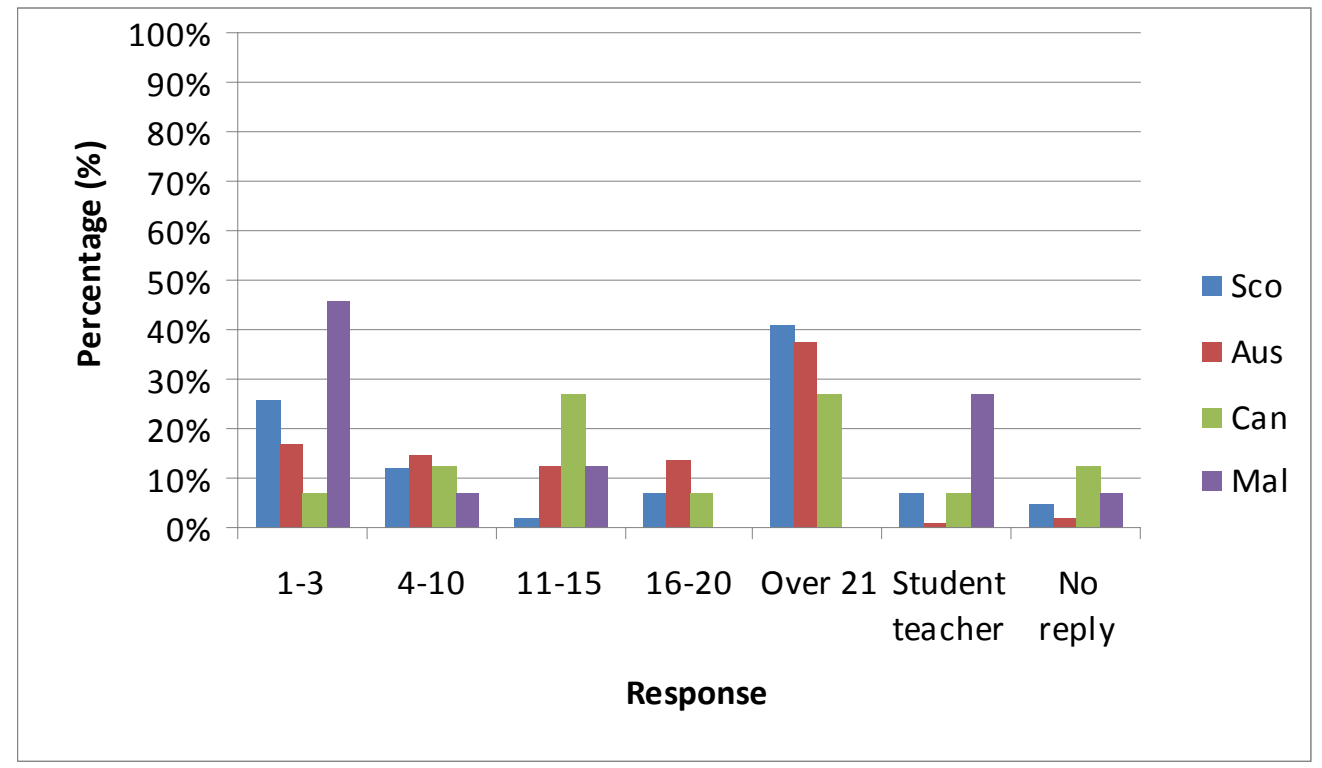

\section{Positioning sustainable development education}

Respondents were asked to indicate their degree of agreement with four statements about sustainable development.

Statement 1 - Schools should prepare pupils to deal with sustainable development issues There was overwhelming agreement that sustainability issues should be taught in schools, with $100 \%$ of Canadian and Maltese respondents, $99 \%$ of Scottish respondents and $98 \%$ of Australian respondents affirming this position.

Statement 2 - The current school system prepares pupils to deal with sustainable development issues

Teachers' perceptions about what schools are currently doing to address this were varied (see Figure 2) with just one a quarter of Australian and Canadian teachers reporting that their current school systems prepare students to become informed consumers who can make responsible decisions regarding the environment and the quality of lives of individuals.

Figure 2: The current school system prepares pupils to deal with sustainable development issues: Comparison of responses from Scottish, Australian, Canadian and Maltese teachers

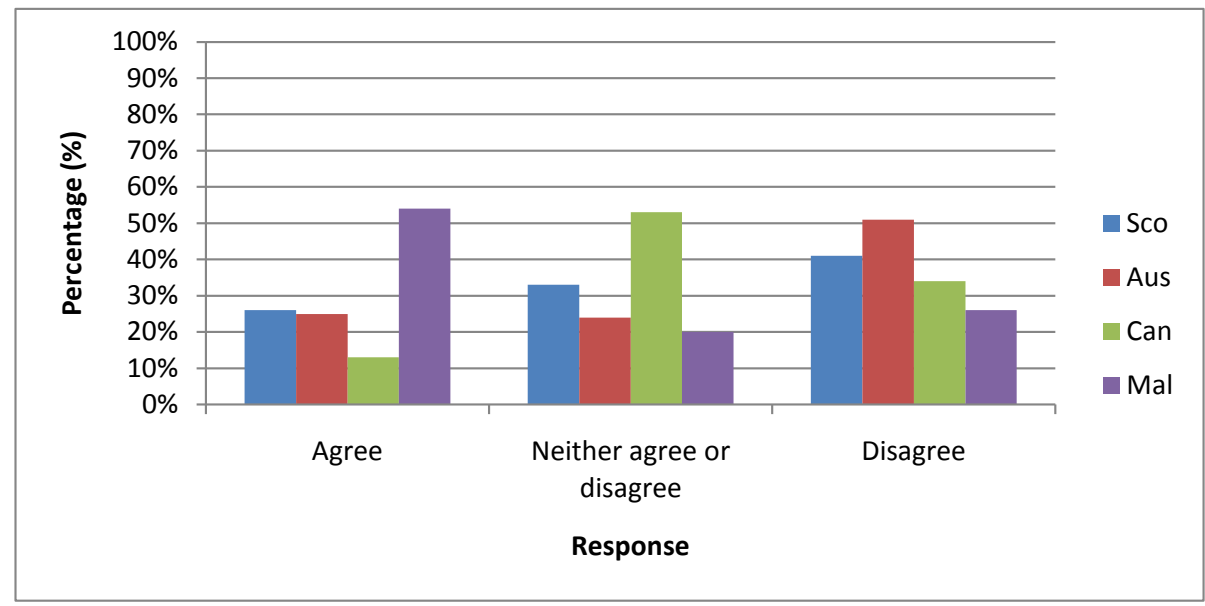

Statement 3 - Pupils need to learn about sustainable development issues in Home Economics 
Very high responses indicated common agreement that pupils should learn about sustainable development issues in home economics (Canada 100\%, Malta 94\%, Scotland 93\%, Australia 93\%).

Statement 4 - I feel confident teaching about sustainable development

When respondents were asked to report their confidence to teach abut sustainable development education, there was considerable variation between the four cohorts. Confidence of home economics teachers to educate students on sustainability issues was stronger with the Maltese cohort (see Figure 3 - Malta 94\%, Australia 71\%, Canada 67\%, and Scotland 54\%) reporting feeling capable to teach this area of the curriculum.

Figure 3: I feel confident teaching about sustainable development issues: Comparison of responses from Scottish, Australian, Canadian and Maltese teachers

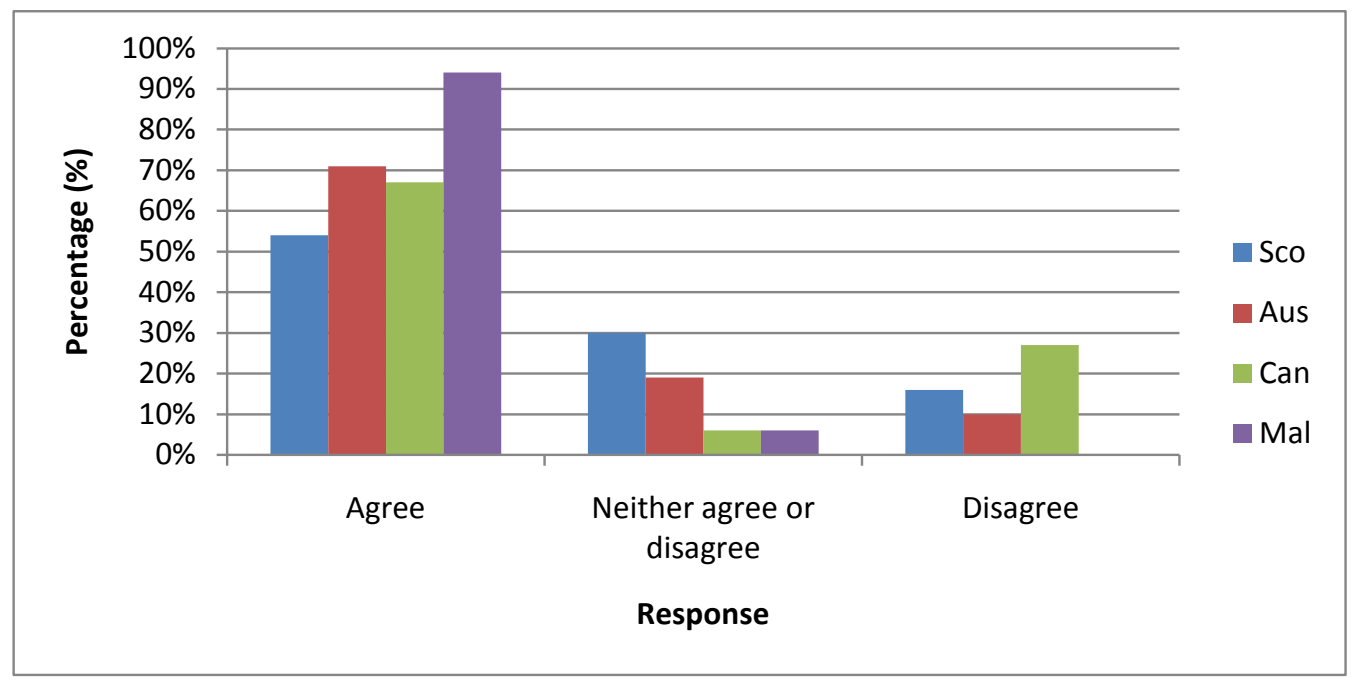

\section{Approaches and intentions}

The vast majority of teachers from all four countries chose between one and three statements to describe their approaches and intentions regarding planning and teaching aspects of sustainability. Several interesting and optimistic findings emerge. Figure 4 corroborates the view that respondents expressed in the early part of the survey, where the overwhelming majority were affirmative about the major contribution home economics could make to sustainable development education. Overall, current practices point to strong intentions of home economics teachers, especially in Canada, to become more involved in planning and teaching aspects of sustainability (Canada 80\%, Scotland 62\%, Australia $51 \%$, Malta 40\%) and a small minority (Australia 8\%, Scotland 6\%) teach no sustainability issues. While figures for the intention to develop lessons (Scotland 36\%, Canada 33\%, Australia 24\%, Malta 20\%), are not compatible with these teachers' intentions to increase involvement, the potency of contemporary national curriculum design may be one of several impediments. Forty per cent of Maltese respondents teach sustainability in the context of home economics regularly, while Canada (67\%), Scotland (51\%) Australia (49\%) and Malta (20\%) do so occasionally. Occasional cross curricular learning opportunities were identified by between a quarter and a fifth of teachers (Scotland 26\%, Canada 20\%, Malta 20\%, Australia $19 \%$ ).

Figure 4: Approaches to teaching about sustainable development: Comparison of responses from Scottish, Australian, Canadian and Maltese teachers 


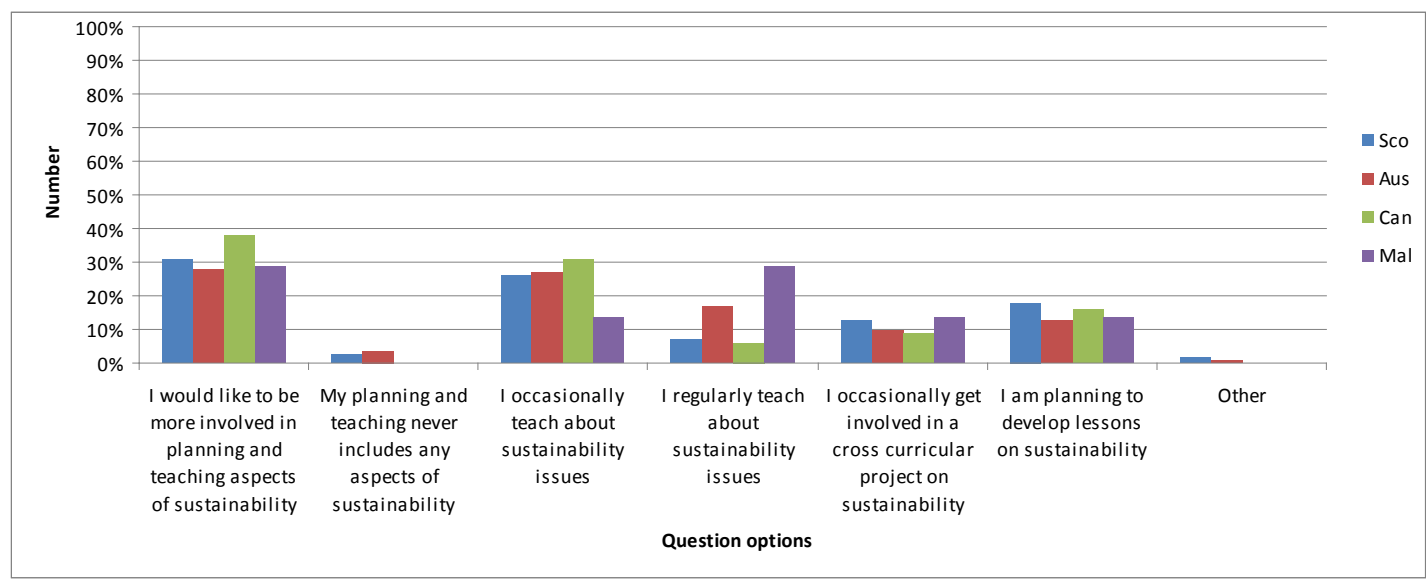

\section{Defining sustainability/sustainable development}

Respondents were asked to define sustainable development education. A small number of respondents (Australia 19\%, Scotland 13\%) offered no answer or stated that they were unsure, for example:

Very important issue but I would like to be better equipped before I start introducing this into my teaching (Scotland).

The majority of respondents included at least two aspects of sustainability in their responses and these were then assigned to eight themes distilled from the responses. Many responses were linked empathetically to the dimension, quality of life and human dimension (Malta $29 \%$, Australia 17\%, Canada 13\%, Scotland 11.5\%) and were particularly futures oriented, as represented in the following comments:

...without compromising the ability of future generations to meet their needs- health, social, environmental, economics (Canada).

Being capable of dealing with human needs... (Malta).

Table 1 presents a summary of the eight themes and the frequency these were indicated by respondents.

Table 1: Definitions of sustainability: Comparison of responses from Scottish, Australian, Canadian and Maltese teachers

\begin{tabular}{|l|c|c|c|c|}
\hline \multicolumn{1}{|c|}{ Dimensions } & $\begin{array}{c}\text { \% on total } \\
\mathbf{1 1 5} \\
\text { Scotland }\end{array}$ & $\begin{array}{c}\text { \% on total } \\
\mathbf{1 1 9} \\
\text { Australia }\end{array}$ & $\begin{array}{c}\text { \% on total } \\
\mathbf{4 8} \\
\text { Canada }\end{array}$ & $\begin{array}{c}\text { \% on total } \\
\mathbf{3 1} \\
\text { Malta }\end{array}$ \\
\hline Food chain & 13 & 7 & 10 & 0 \\
\hline Local perspectives & 9 & 7 & 6 & 0 \\
\hline $\begin{array}{l}\text { Environmental and global } \\
\text { perspectives }\end{array}$ & 24.5 & 26 & 39 & 32 \\
\hline $\begin{array}{l}\text { Quality of life/human } \\
\text { considerations }\end{array}$ & 11.5 & 17 & 13 & 29 \\
\hline $\begin{array}{l}\text { Resource utilization and } \\
\text { management }\end{array}$ & 18 & 31 & 16 & 26 \\
\hline $\begin{array}{l}\text { Consumer choice and } \\
\text { actions }\end{array}$ & 16 & 7 & 2 & 3 \\
\hline
\end{tabular}




\begin{tabular}{|lc|c|c|c|c|}
\hline Ethics & 8 & 5 & 10 & 7 \\
\hline Interdependence & & 0 & 0 & 4 & 3 \\
\hline & Total & $100 \%$ & $100 \%$ & $100 \%$ & $100 \%$ \\
\hline
\end{tabular}

Not surprisingly, the dimensions sit comfortably in the context of home economics and responses illustrate that those who did respond understand sustainability principles.

If we use materials in the environment to create products - the ability to replace these products so there is no loss (Australia).

Using resources with the same rate by which they are being regenerated (Malta).

Respondents were less concerned with the transmission of knowledge but expressed a more emancipatory purpose, where pupils are encouraged to explore and challenge their own values, attitudes and behaviours:

Encouraging pupils to develop ethical attitudes as well as knowledge to make informed choices and think about the impact we have on the earth (Scotland).

....empowers students to feel they can make a difference (Australia).

...develop attitudes and skills which help the individual to make informed decisions... (Malta)

Of the eight dimensions identified in the responses, the three most common dimensions (environmental and global perspectives; quality of life/human considerations and resource utilization and management) were the same for three cohorts (Australia, Canada and Malta) but with a different order of priority. The fourth cohort, Scotland also prioritised human impact with environmental and global perspectives and resource utilization and management, alongside consumer choice and actions.

...make the best of current resources... and even better, to develop a

'fairness' and appreciation of systems and their effects (Scotland).

... to move away from a throw away society we have become (Canada).

An awareness of current production and development practices to identify opportunities and challenges for improvements or new systems/practices (Australia).

When the responses to this question are mapped visually, the following web emerges, demonstrating that of the eight themes that emerged from the data, there is a high degree of similarity from the respondents across the four countries, see Figure 5. 
Figure 5: Definitions of sustainability: Comparison of responses from Scottish, Australian, Canadian and Maltese teachers

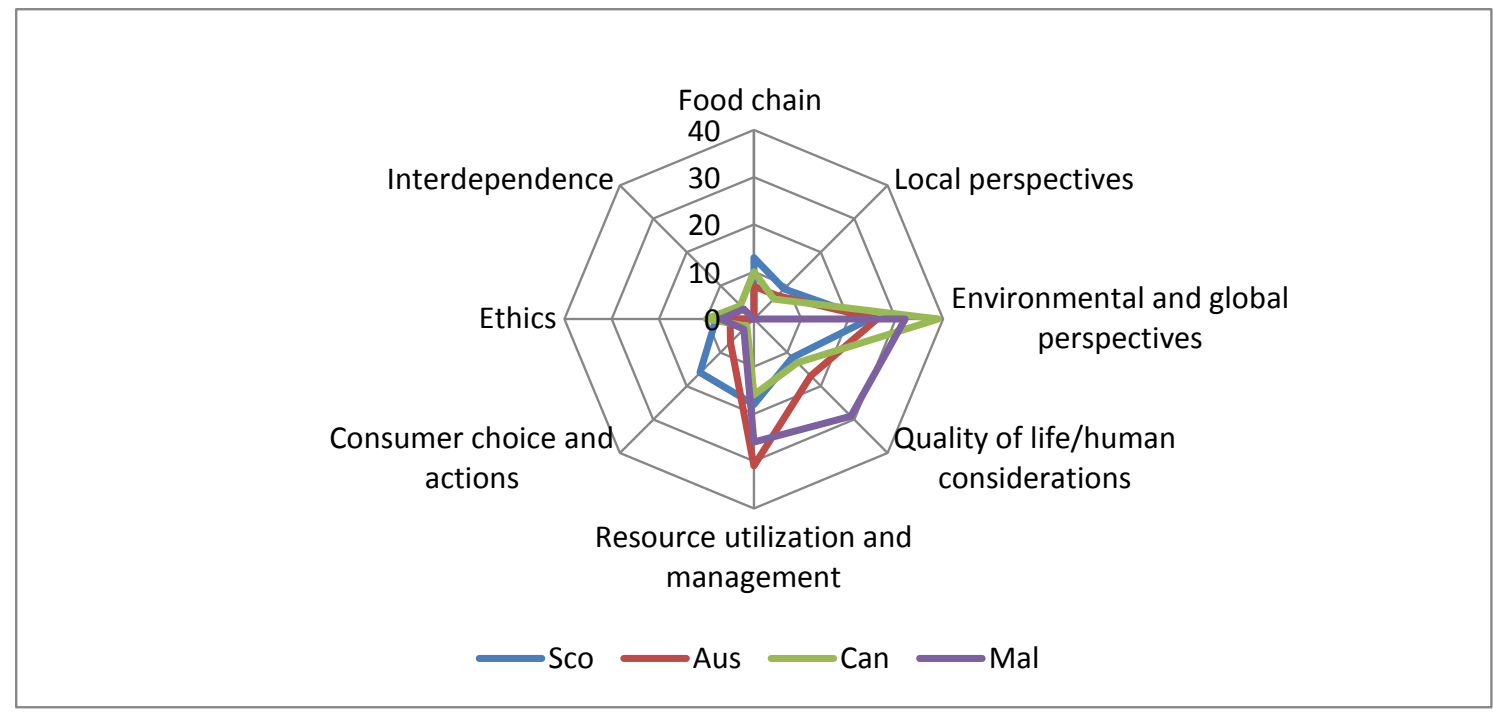

\section{Reported home economics teacher practices related to sustainability education}

Closely related to this definitional understanding of sustainability education, respondents were asked to report home economics practices that relate to sustainability education. A total of 315 comments were provided in response to this question. The responses were grouped into the same themes used for the definitions, given their similarity. The frequency that the themes were reported for each country were then tabulated and are provided in Figure 6.

Figure 6: Eight key themes - what are you already doing that is related to sustainability education: Comparison of responses from Scottish, Australian, Canadian and Maltese teachers

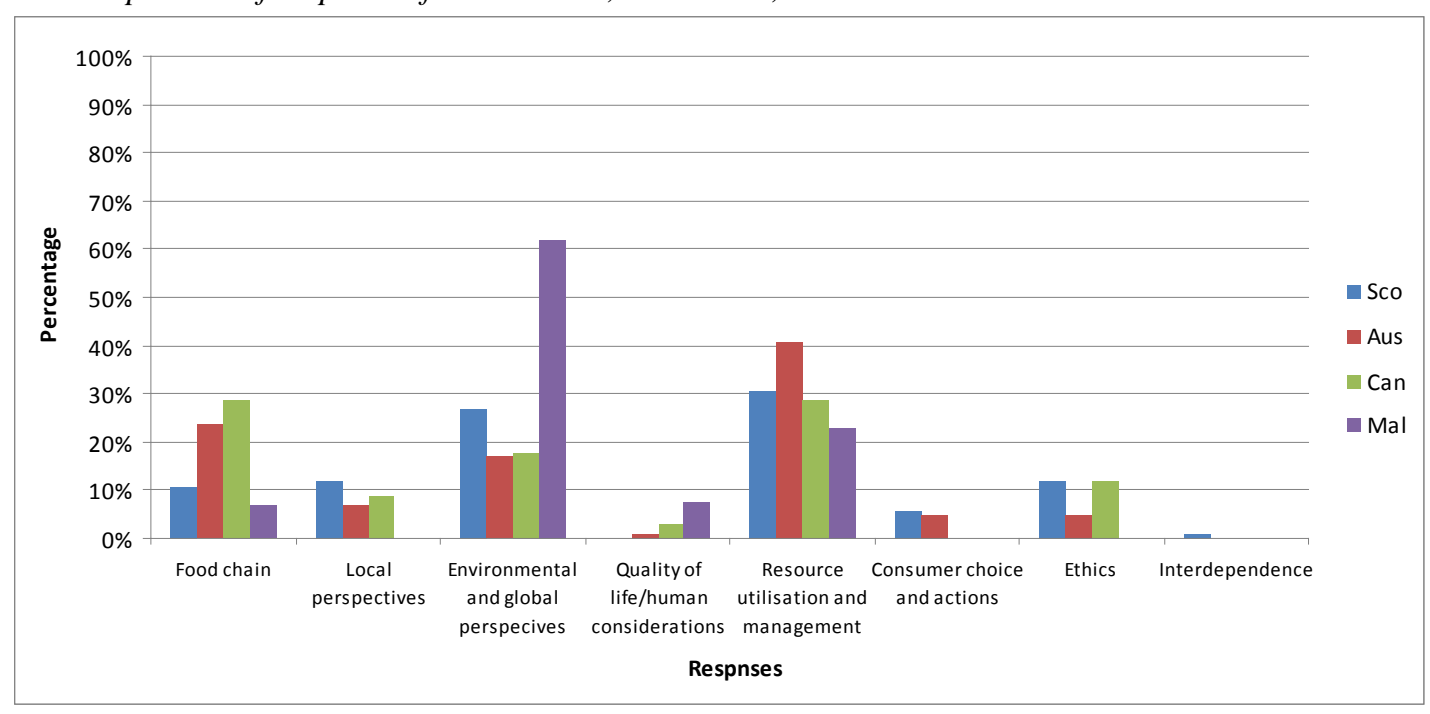

For Scotland, Australia and Canada, the theme 'resource utilisation and management' was the most frequently reported by respondents as being part of the current practice of home economics teachers. For the Maltese respondents, 'environmental and global perspectives' was reported by more than $60 \%$ of respondents, making it the most common theme. 


\section{Responsibility to teach sustainability education}

When asked whose responsibility it was to teach sustainability, home economics teachers suggested a range of contributors such as the media, peers, everyone, outside agencies and experts in the field, business and commerce sectors but these were marginal in terms of responses. Predictably the most significant contributors were teachers/school and home/family for all four cohorts with over one third in each country identifying the former and over one quarter in each country identifying the latter. The individual differences in Figure 7 illustrate the cultural, political and educational situations in each of the countries. Australia expects Government (10\%) and the wider community (14\%) to share responsibility of teaching sustainability, while Malta (13\%) especially, but also Canada (9\%) and Scotland (7\%) expect the interdisciplinary strategies in school to play a noteworthy role.

Figure 7: Responsibility for teaching sustainability: Comparison of responses from Scottish, Australian, Canadian and Maltese teachers

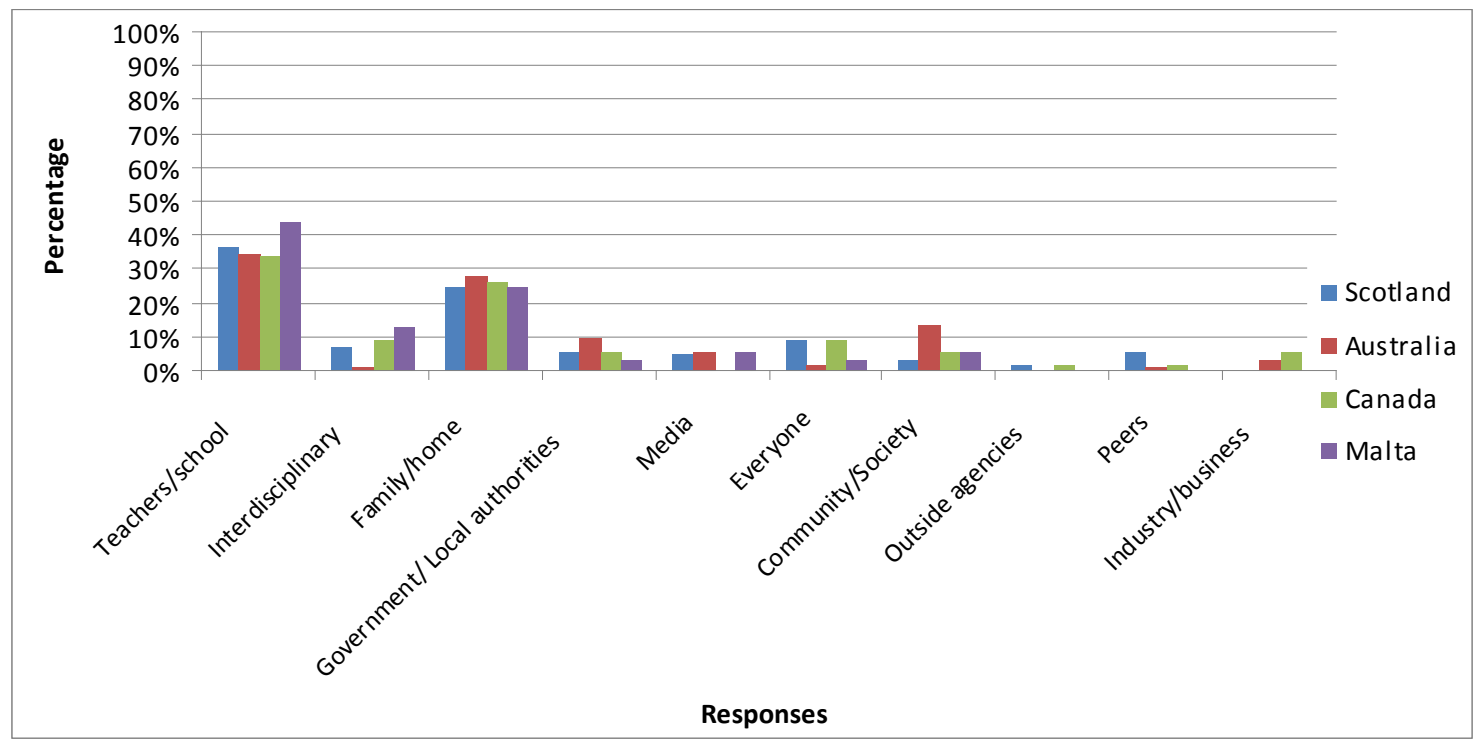

\section{Reported interest to teach}

Respondents were asked to identify, from a predetermined list of 21 items, with the option of adding others, what areas related to sustainable development education they would be interested to teach.

Table 2 illustrates the rank ordering of the five most popular choices made by the home economics teacher respondents. The eclectic mix from each country may be indicative of the variety of curricula and personal choice of and confidence in topics by teachers. While the results suggest few cultural differences, they journey across several global environmental issues. Several respondents took the opportunity to make broader comments, reiterating the positive intentions suggested in earlier questions but also highlighting uneasy and searching positions:

Any or all of the above but I'd need resources/lesson plans to help me (Australia).

Although I'm interested to teach about anything since they are all interesting, our syllabus is already too vast (Malta).

I believe that HE teachers are in a prime subject area to teach these topics (Canada). 
Table 2: Top 5 Home Economics teachers' particular teaching interests related to sustainability: Comparison of responses from Scotland, Australia, Canada and Malta.

\begin{tabular}{|c|c|c|c|}
\hline Scotland & Australia & Canada & Malta \\
\hline $\begin{array}{ll}\text { - } & \text { Waste, } \\
\text { recycling and } \\
\text { reuse } \\
\text { - } & \text { Food miles/ } \\
\text { reducing the } \\
\text { carbon footprint } \\
\text { - } & \text { Organic foods } \\
\text { - } & \text { Buying locally } \\
\text { - } & \text { Fairtrade }\end{array}$ & $\begin{array}{ll}\text { - } & \text { Climate change } \\
\text { and its effect on } \\
\text { food production } \\
\text { - } \text { Fairtrade } \\
\text { - Health and the } \\
\text { environment } \\
\text { - Energy } \\
\text { - Cross- } \\
\text { curricular } \\
\text { projects }\end{array}$ & $\begin{array}{ll}\text { - } & \text { Health and the } \\
\text { environment } \\
\text { - } \\
\text { Cross- } \\
\text { curricular } \\
\text { projects } \\
\text { - Eco friendly } \\
\text { products } \\
\text { - Environment } \\
\text { - Food Miles/ } \\
\text { reducing the } \\
\text { carbon footprint }\end{array}$ & $\begin{array}{ll}\text { - } & \text { Buying locally } \\
\text { - } & \text { Healthy seas } \\
\text { - } & \text { The use and } \\
\text { abuse of } \\
\text { resources and } \\
\text { materials in the } \\
\text { home } \\
\text { - } \text { Eco shopping } \\
\text { - Food miles/ } \\
\text { reducing the } \\
\text { carbon footprint }\end{array}$ \\
\hline
\end{tabular}

\section{DISCUSSION}

This aim of this study was to explore the intentions, beliefs and practices of home economics teachers with respect to sustainable development education, from a cross-cultural perspective. The findings reveal the similarities and differences in four countries around the world. Importantly, the data reveals that there is agreement in all four countries of the importance of education for sustainable development, and of the key role home economics education has in delivering this education. Interestingly, the respondents in this study did not believe that the current education system effectively prepares pupils to deal with sustainable development issues.

Of the four datasets compared in this study, there is a high degree of consistency from respondents in Canada, Australia and Scotland. The data from the Maltese respondents differed in several regards, as outlined in the results section, and it is speculated that this may reflect the sample (mostly in their first 3 years of teaching or currently undertaking teacher education), which differed from the more experienced respondents in the other countries.

Regardless of these similarities and differences, all home economists around the world are guided by the IFHE Position Statement that clearly stipulates the relationship between home economics education and sustainable practices (IFHE, 2008). Given this global framework for understanding, the value of the subject to contribute to sustainable development education should be expected to be evident in the data generated from this study.

While this study did not observe actual classroom practice and pedagogical approaches to synthesise and validate the suggested connections between beliefs and classroom practice, it points to the existence of motivated, ecologically ethical home economics teachers who have considerable concern about sustainability. These teachers may play an important role in the expansion of sustainability development education, in whatever form it may take. Furthermore, the respondents indicated a high degree of subject area competence and confidence, indicating their relatively high levels of self-efficacy for the teaching of curriculum addressing sustainability education. 
As noted in the early sections of this paper, education for sustainability requires an understanding of the interconnections and interdependence of humans and the environment. Opportunities to teach in this way must be revisited by home economics teachers to consciously orchestrate its place in this area of school curricula and to critically engage with this agenda. A challenging climate of debate and practice is necessary when curriculum conditions are fertile as they presently are and there is a leadership/coordination role available for home economics if they want to manage such conversation (Clifford, 2008). Presently, many secondary schools are reconsidering this pedagogical approach and home economics must see this as an opportunity. Evidence presented in this paper suggests that home economics teachers are willing partners, despite not being regarded as contributing to sustainable education, as noted at the outset of this paper. This is an inhibiting factor affecting the capacity of schools to achieve sustainable development goals.

Given the need for a global approach to sustainability, the International Federation for Home Economics (IFHE) with members operating at local, national and international levels is positioned to make a significant impact in promoting and enacting the educational imperatives for securing sustainable futures. The Institute would claim to agree with the characteristics noted by Smyth \& Shacklock (1998) as required by future global citizens, viz: looking at problems in a global context; working co-operatively and responsibly; accepting cultural difference; thinking in a critical and systematic way; solving conflicts non-violently; changing lifestyles to protect the environment; defending human rights; and participating in politics. Further study is recommended to investigate the ways in which the field specifically contributes to the development of future global citizens, through the vehicle of sustainable development education knowledge and practices. 


\section{REFERENCES}

Arai, N. (2008) Developing Home Economics Curricula to Nurture Consumer Citizenship for Sustainable Development. E-Book Education for Global Sustainable Development: a Challenge for Consumer Citizens.

Available: http://www.educationforsustainabledevelopment.org/map.html

[Date Accessed 30 June 2010]

Blumstein, D. T. \& Saylan, C. (2007) The Failure of Environmental Education (and How We Can Fix It). PLoS Biology; 5(5), e120

Available: http://www.pubmedcentral.nih.gov/articlerender.fcgi?artid=1847843,]

[Date Accessed 23 June 2010]

Cavana, R.Y., Delahaye, B.L., \& Sekaran, U. (2003). Applied business research: Qualitative and quantitative methods. Brisbane, Queensland: John Wiley and Sons.

Clifford, A. (2008) Education for Sustainable Development: Consumer citizens in e-dialogue. Launch Paper for E-Book Education for Global Sustainable Development: a Challenge for Consumer Citizens. IFHE Congress, Lucerne, Switzerland 2008.

Available: http://www.educationforsustainabledevelopment.org/map.html

[Date Accessed 11 November 2009]

Craig, C. (2009) Flights from the field and the plight of teacher education: a personal perspective. Journal of Curriculum Studies; 41(5), 605-624.

Dewhurst, Y. \& Pendergast, D. (2008) he21C: A cross cultural comparative study. International Journal of Home Economics; 1(1), 63-87.

Dewhurst, Y. \& Pendergast, D. (2009) Daring to lead: Global perceptions of the IFHE Position Statement Home Economics in the 21st Century. Journal of the Home Economics Institute of Australia; 16(2) 21-32.

Earth Charter

http://www.unesco.org/en/esd/programme/ethical-principles/the-earth-charter/\#c16492

[Date accessed: 18 June 2010]

Fien, J. (1993) Education for the environment: critical curriculum theorising and environmental education. Geelong: Deakin University.

Gough, A. (1997) Education and the Environment: Policy, Trends and the Problems of Marginalisation. Melbourne, Australia: Australian Council for Educational Research.

Gruemewald, D. A. \& Manteaw, B. O. (2007) Oil and water still: how No Child Left Behind limits and distorts environmental education in US schools. Environmental Education Research; 13(2), 171-188.

He, M. F., Phillion, J., Chan, E. \& Xu, S. (2008) Immigrant students' experience of curriculum. In F. M. Connelly, M. F. He \& J. Phillion (eds), The SAGE Handbook of Curriculum and Instruction (Los Angeles, CA: Sage), 219-239. 
Heimlich, J. E. , Braus, J. , Olivolo, B. , McKeown-Ice, R. \& Barringer-Smith, L. (2004) Environmental Education and Preservice Teacher Preparation: A National Study. Journal of Environmental Education; 35(2) 17-21.

Hopkins, C. \& McKeown, R. (2002) ESD: an international perspective, in: D. Tilbury, R. B, Stevenson, J. Fien \& D. Schreuder (Eds) Education for Sustainability: responding to the global challenge (Gland, Switzerland and Cambridge, UK, IUCN Commission on Education and Communication).

International Federation for Home Economics (2008) IFHE Position Statement, Home Economics in the $21^{\text {st }}$ Century.

Available:

http://www.ifhe.org/index.php?eID=tx_nawsecuredl\&u=0\&file=fileadmin/user_upload/redak tion/Publications/IFHE_Position_Statement_2008.pdf\&t=1276950317\&hash=0878b56fbd9e a1b52ab4858efac2927c]

[Date Accessed 18 June 2010]

International Union for the Conservation of Nature., N. R., The United Nations Environmental Programme., \& World Conservation Foundation (1980) World conservation strategy: Living resource conservation for sustainable development. Gland, Switzerland: International Union for the Conservation of Nature and Natural Resources.

Krippendorff, K. (2004). Content analysis: An introduction to its methodology, 2nd ed. Beverly Hills, CA: Sage.

McKeown, R. \& Hopkins, C. (2003) $\neq$ EESD: defusing the worry. Environmental Education Research; 9(1), 117-128.

Millenium EcoSystem Assessment Board (2005) Living Beyond Our Means: Natural Assets and Human Well-being.

Available at: http://www.millenniumassessment.org/documents/document.429.aspx.pdf

[Date accessed: 11 November 2009]

Moroyne, C. M. (2009) Complementary curriculum: the work of ecologically minded teachers. Journal of Curriculum Studies; 41(6), 789-811.

Nielsen, S.S \& Gottschau, J. (2008) Cross-Disciplinary Consumer Citizenship Education. EBook Education for Global Sustainable Development: a Challenge for Consumer Citizens.

Available: http://www.educationforsustainabledevelopment.org/map.html

[Date Accessed 30 June 2010]

Oskamp, S. (2000) A sustainable future for humanity? How can psychology help? American Psychologist; 55, 496-508.

Pendergast, D. (2006) Sustaining the home economics profession in new times - A convergent moment. In: Rauma, A., Pollanen, S. \& Seitamaa-Hakkarainen, P. (Eds). Human Perspectives on Sustainable Future. Joensuu, Finland: University of Joensuu

Ranganathan, J \& Irwin, F. (2007) Restoring Nature's Capital: An Action Agenda to Sustain Ecosystem Services. 
Available: http://www.wri.org/publication/restoring-natures-capital

[Date Accessed: 22 June 2010]

Smyth, J. \& Shacklock, G. (1998) Re-Making Teaching: Ideology, policy and practice. London: Routledge.

Summers, M., Kruger, C., Childs, A., Mant, A. (2000) One Small Step Understanding the Science of Environmental Issues. Hatfield: The Association of Science Education.

Suzuki, D. (1993) Time to change. Canada: Allen \& Unwin Pty Ltd.

UNESCO-UNEP (1976) The Belgrade Charter. Connect; 1(1). UNESCO, Paris.

UNESCO (1977) Education and the Challenge of Environmental Problems. Intergovernmental Conference on Educational Education, Document ED-77/conf.230/Col.3. also UNESCO/ENVED 4. UNESCO, Paris.

UNESCO (1978) Final report of intergovernmental conference on environmental education. Organized by UNESCO in cooperation with UNEP, Tbilisi, USSR, 14-26

UNESCO (2010) Strategy for the Second half of the United Nations Decade of Education for Sustainable Development. Paris: UNESCO Education Sector.

United Nations (2002) World Summit on Sustainable Development: Plan of Implementation. Paper presented at the World Summit on Sustainable Development, Johannesburg, South Africa.

United Nations Department of Public Information (1992) DPI/1344/Rev.1-97-018888February 1997-5m, Earth Summit Agenda 21 The United Nations Programme of Action From Rio.

Van Kannel-Ray, N. (2006) Guiding principles and emerging practices for environmentally sustainable education. Curriculum and Teaching Dialogue; 8(1/2), 113-123.

Wallen, N., \& Fraenkel, J. (2001). Educational research: A guide to the process (2 ${ }^{\text {nd }}$ Ed.). Mahwah, New Jersey: Lawrence Erlbaum. 